\title{
Analysis of Higher-Order Thinking Skills (Hots) Items in Senior High School English National Examination 2019
}

\author{
Nurul Wahyuni Ilham ${ }^{1}$ \\ hj.geminastitisakkir@yahoo.com \\ Baso Jabu ${ }^{2}$ \\ basojabu@unm.ac.id \\ Chairil Anwar Korompot ${ }^{3}$ \\ cakorompot@unm.ac.id
}

\author{
${ }^{1}$ Student, English Education Department, Universitas Negeri Makassar, Indonesia \\ ${ }^{2,3}$ Lecturers, English Education Department, Universitas Negeri Makassar, Indonesia
}

\begin{abstract}
In order to fulfill the 21 'st century skills, the implementation of HOTS items to enhance students' reasoning skills is deemed important. Nonetheless, we need to observe more about the extent and specific dimensions of HOTS applied in the English National Examination in Indonesia. The present study, therefore aimed to classify the items that fulfilled the indicators of HOTS items in ENE 2019 and specific dimension of knowledge types and dimension of cognitive process skills of the HOTS items. The results showed there was a sufficient total of a HOTS item in ENE 2019. Out of 35 questions, 15 (42.86\%) were considered as HOTS items. The second finding was the dimension of cognitive process skills were on the stage of Analyze and Create. The findings indicated that ENE 2019 already had sufficient amount of HOTS items, although the distribution of the cognitive abilities is still monotonous. It was suggested for the exam developers to implement adequate proportion of the HOTS cognitive abilities to enhance students' HOTS.
\end{abstract}

Keyword: Higher- Order Thinking Skills, Taxonomy, Examination

\section{INTRODUCTION}

Higher-Order Thinking Skills (HOTS) is an important skill in learning in the 21'st century. HOTS are known as the expansion of mind where a person should evaluate or analyze the answer or to modify the information because the right answer is not always learned from the everyday routine or experience (Onosko \& Newman, 1994 in Hassan et al., 2017: p. 101). The Indonesian government has tried to incorporate HOTS in the school 
curriculum. As the implication of the education policy, the educational assessments, particularly English National Examination (ENE) are encouraged to be grounded on the principle of HOTS. The National Examination (UN) questions are directed to better measure students' reasoning ability (POS UN 2019, article 6). The government continues to strive to increase the proportion of HOTS items in UN every year. Indonesian government hopes that by applying HOTS, students can accomplish various competencies like critical thinking, creative and innovative, communication skill, collaborative, and confidence (Ariyana, Pudjiastuti, Bestary, \& Zamroni, 2018: p.2; Sakkir, 2018; Syatrinan, 2020).

One of the purposes of $\mathrm{UN}$ is as a depiction of the excellence of education unit or programs. As UN has an important role in the improvement of Indonesia's education quality, assessing and evaluating the ENE items is necessary to be done. Analyzing items of test items also part of test evaluation process. It really is necessary to analyze the ENE to assess the extent of questions of HOTS included in the ENE. Furthermore, this is to make sure that the government's expectation is carried out. Although some work has been done on the analysis of UN items, there seems to be a deficiency of discussion on the analysis from the most recent ENE and the cognitive processing abilities of the HOTS items in ENE. In fact, the English National Examination (hereafter ENE) questions so far are still dominated with questions that require Lower-Order Thinking Skills (hereafter LOTS). While the questions requiring Higher-Order Thinking Skills (hereafter HOTS) still have small proportion. So, this study aimed to classify the items that fulfilled the indicators of HOTS items in ENE 2019 and specific dimension of knowledge types and dimension of cognitive process skills of the HOTS items.

\section{LITERATURE REVIEW}

Lewis \& Smith (1993) concluded that HOTS occurs when new knowledge and the information stored in memory is interconnected, reorganized, and extended to achieve goals or find possible answers in confusing situations. HOTS demand students to critically analyze knowledge, draw inferences, and make generalizations. They will also generate original communication, provide predictions, offer solutions, construct and solve problems related to everyday life, evaluate concepts, express opinions and make decisions and choices. (Rajendran, 2001: p.3-4).

Bloom's Taxonomy has been implemented in the field of education in a number of ways including providing insight into the type questions asked by educators in classroom instruction and providing plans to guide educators in formulating examination questions to make sure that a range of cognitive processes are included (Reeves, 2012; Sakkir, 2019). In 2001, Anderson, Krathwhol and other colleagues revised the original version of Bloom's Taxonomy and named it Bloom's Revised Taxonomy. It then became a two-dimensional framework, dimension of knowledge types and dimension of cognitive process. The dimension of cognitive process consists of skills Remember, Understand, Apply, Analyze, Evaluate, and Create of which the last three skills are considered as HOTS. 
Table 1 Dimension of Cognitive Process of the Revised Bloom's Taxonomy

\begin{tabular}{l} 
The Cognitive Process Dimension of the Revised Taxonomy \\
\hline 1.0 Remember - Recognizing, Recalling \\
\hline 2.0 Understand - Interpreting, Exemplifiying, Classifying, Summarizing, \\
Inferring, Comparing, Explaining \\
\hline 3.0 Apply - Executing, Implementing \\
\hline 4.0 Analyze - Differentiating, Organizing, Attributing \\
\hline 5.0 Evaluate - Checking, Critiquing \\
\hline 6.0 Create - Generating, Planning, Producing \\
\hline
\end{tabular}

In concluding whether an item assesses HOTS or not, Directorate of High School Development (2017) has developed an instrument of HOTS item analysis. The instrument assesses various aspects based on the characteristics of HOTS questions, which are: (1) Uses interesting stimulus that is novel and encourage students to read; (2) Uses contextual stimulus in the form of picture, graphic, text, visualization which relates to real-life situations; (3) Assesses the cognitive level of reasoning (Analyze, Evaluate, and Create); (4) The answer is not explicitly stated on the stimulus; (5) The answer choices are homogenous and logical in terms of material; (6) Each question must have one correct answer.

\section{METHOD}

The method of research was descriptive method of document analysis because the data collected in this research came from official documents, Senior High School ENE 2019. The object of this research was the reading section of ENE 2019. Purposive sampling technique was used to select the most recent ENE. The instrument of the research was the document of ENE 2019. Another instrument was instrument of HOTS item analysis for multiple-choice items to examine and classify if the item is a HOTS item or not.

The writer compiled 35 questions of reading section and examined each question in accordance with certain aspects in the instrument. If the question fulfilled the indicators, check mark was given in the column. For a question to be listed as HOTS item, it must fulfill all the indicators. After that, the researcher calculated the percentage ratio of the presence of HOTS items in ENE 2019.

\section{FINDINGS AND DISCUSSIONS}

It was found from the analysis results that 15 (42.9\%) out of 35 questions of ENE 2019 are categorized as HOTS items because they fulfilled all the indicators of HOTS item and $20(57.1 \%)$ out of 35 questions are categorized as LOTS because they didn't meet all the indicators of HOTS item.

Table 2 The Frequency and Percentage of HOTS Items in ENE 2019 


\begin{tabular}{|c|c|c|}
\hline Level & & sult \\
\hline & Frequency $(\mathbf{N})$ & Percentage (\%) \\
\hline $\begin{array}{l}\text { LOTS (didn't fulfill all } \\
\text { indicators of HOTS item) }\end{array}$ & 20 & $57.1 \%$ \\
\hline $\begin{array}{l}\text { HOTS (fulfilled all } \\
\text { indicators of HOTS item) }\end{array}$ & 15 & $42.9 \%$ \\
\hline
\end{tabular}

According to the analysis, the results indicated that even though ENE 2019 was still dominated with LOTS items, there was already a sufficient total of HOTS items which is almost half of the reading section questions are categorized as HOTS items.

Table 3 Samples of LOTS and HOTS Items

\begin{tabular}{|c|c|}
\hline Level & Result \\
\hline LOTS & $\begin{array}{l}\text { 30. What should be completed after dipping the cloth into the } \\
\text { vinegar mixture? } \\
\text { A. Keeping the blow dryer } 3 \text { to } 4 \text { inches away from the table } \\
\text { B. Softening dried wax with a blow dryer on medium heat } \\
\text { C. Blotting up the softened wax with a soft cloth } \\
\text { D. Never leave burning candle unattended } \\
\text { E. Wiping away any leftover wax }\end{array}$ \\
\hline HOTS & $\begin{array}{l}\text { 32. The writer's purpose of the text is? } \\
\text { A. to describe to the readers about skateboard in general } \\
\text { B. to inform the readers about skateboarding equipemnt } \\
\text { C. to explain how skateboards are classified } \\
\text { D. to entertain the readers by describing skateboard } \\
\text { E. to persuade the readers to try skateboarding }\end{array}$ \\
\hline
\end{tabular}

Table 3 presents the samples of LOTS and HOTS item. Question number 30 is not a HOTS item because it didn't meet all the indicators of HOTS meanwhile question number 32 is categorized as a HOTS item because it fulfilled all the indicators of HOTS item. The following table is a depiction of the fulfillment of HOTS item indicators for question number 30 and 32.

Table 4 The Fulfillment of HOTS Item Indicators for the Question Samples

\begin{tabular}{llcc}
\hline \multirow{2}{*}{ No } & \multicolumn{1}{c}{ Aspects Analyzed } & \multicolumn{2}{c}{$\begin{array}{c}\text { Item } \\
\text { Number }\end{array}$} \\
\cline { 3 - 5 } & $\begin{array}{l}\mathbf{3 0} \\
\text { The item uses interesting stimulus (new, encourage learners to } \\
\text { read) }\end{array}$ & $\mathrm{V}$ & $\mathrm{V}$ \\
\hline 2 & $\begin{array}{l}\text { The item uses contextual stimulus (picture/graphic, text, } \\
\text { visualization involved to everyday life) }\end{array}$ & $\mathrm{V}$ & $\mathrm{V}$ \\
\hline 3 & $\begin{array}{l}\text { Assesses cognitive stage of reasoning (analyze, evaluate, and } \\
\text { create) }\end{array}$ & $\mathrm{X}$ & $\mathrm{V}$ \\
\hline 4 & The answer is not explicitly stated in the text & $\mathrm{X}$ & $\mathrm{V}$ \\
\hline
\end{tabular}




\begin{tabular}{llll}
\hline 5 & Choices of answer are homogenous and logical & V & V \\
\hline 6 & Each question only has one correct answer & V & V \\
\hline
\end{tabular}

Question number 32 "The writer's purpose of the text is?" which is categorized as HOTS item because it fulfilled the indicators. It used interesting and contextual stimulus in the form of descriptive text. Answer choices were homogeneous, logical, and only had one correct answer. Moreover, the answer was not explicitly stated in the text, also it assessed students' higher order thinking. Students need to administer stages of thinking process to find the answer. First, students read the text in order to comprehend the facts and information presented. Second, they processed and analyzed the knowledge by breaking them into parts and determined how the parts relate to one another to get the main idea of the text. After that, they transfer and process the knowledge to determine the writer's intention of the text. For those reasons, the item was categorized as a HOTS item. As stated by Brookhart (2010), in terms of transfer, HOTS are conceived as students being able to link their knowledge to other elements beyond those learned to connect with it.

The findings of the research indicated that the government really increased the proportion of HOTS items in ENE every year. ENE 2019 has more HOTS than ENE 2018, according to Putra (2019) who found that in ENE 2018, there were only 10 questions that categorized as HOTS items and in comparison to the last six years of ENE questions, ENE 2019 has far more HOTS items in it. This shows that the authority has so far been consistent in implementing HOTS in the evaluation system for the students to accomplish the 21st century skills. Indonesian government hopes that by applying HOTS, students can accomplish various competencies like critical thinking, creative and innovative, communication skill, collaborative, and confidence (Ariyana, Pudjiastuti, Bestary, \& Zamroni, 2018: p.2).

The next finding is relating the cognitive process levels. The finding shows that all sub skills of Analyze are contained in ENE 2019 and only one sub skill of Create that is included. The total of items categorized in Differentiating sub skill are 3 or $20 \%$. There are 4 or $26.7 \%$ items classified in Organizing sub skill and 6 or $40 \%$ of the HOTS items are classified in Attributing sub skill. In addition, there are 2 or $13.3 \%$ HOTS items categorized in Generating sub skill, under the skill of Create. On the other hand, the findings showed complete absence of HOTS items that assessed the second stage of HOTS, Evaluate.

One sample that is on the stage of Differentiating - a sub skill under Analyze. There are three out of fifteen HOTS items that involved Differentiating sub skill. Question number 34 is one of the samples, "How do you compare paragraph 2 and 3 in terms of the aim?" The question asked students to organize the paragraphs and distinguish the parts of a whole structure in terms of their relevance or importance. Students need to differentiate relevant information from irrelevant information in terms of the aim of the paragraphs. Differentiating is different from comparing - a sub skill correlated with Understand - in using a larger context to determine what is relevant and what is not, and involves structural organization in deciding how the parts fit into the overall structure or whole (Anderson \& Krathwohl, 2001). 
Another sub-skill of Analyze is Attributing. In sub skill Attributing, learners are required to determine view, biases, values or intention underlying communication. There are six out of fifteen HOTS items that fall under sub skill Attributing. One of the samples is question number 32 "The writer's purpose of the text is..." This question assessed sub-skill of Attributing because learners need to determine the author's intention of the presented material (Anderson \& Krathwohl, 2001).

In sub skill Generating - belongs to the skill of Create, the question samples are represented in the form of predicting possible act following the presented material which stated "After reading the news, the readers most likely..." (number 45). This question required students to evaluate the text and generate a hypothesis about the readers' action after reading the text. Generating is coming up with alternative hypotheses based on criteria (Anderson \& Krathwohl, 2001). Given the findings and discussion of the research, even though ENE 2019 has a sufficient total of HOTS items, there is still a lack of variation on the cognitive skills involved in those HOTS items.

\section{CONCLOSIONS}

In conclusion, ENE 2019 has a sufficient total of questions that met the indicators of HOTS items. It indicates the government's determination in improving the quality of students' competency and for students to acquire the 21 st century skills by implementing HOTS assessment in UN. However, the skills of cognitive process only involved Analyze and Create skills with no items that assessed Evaluate skill. It shows that the distribution of skills of the cognitive process of the HOTS items in ENE 2019 is monotonous and lacking of variation. It is expected from the test developers to include more HOTS items in the future form of UN in Indonesia so that it encourages students to learn more critically and creatively in accordance with the 21 st century skills. Also, it is needed so Indonesian students have high competency and can adapt to the rapidly changing world. Moreover, it is expected that the test developers pay more attention to the distribution of cognitive level of the HOTS items. As stated by Ahmad (2016) that ENE needs more attention to evaluative questions in order to lead learners to have the chances to independently express their opinions, feelings, and attitudes which stimulate their way to be creative and innovative thinkers.

\section{REFERENCES}

Ahmad, U. L. (2016). Senior High School English National Examination and Thinking Skills. Beyond Words, 4(2), 168-190.

Anderson, L. W., \& Krathwohl, D. R. (2001). A taxonomy for learning, teaching, and assessing: A revision of Bloom's Taxonomy of educational objectives. Longman.

Ariyana, Y., Pudjiastuti, A., Bestary, R., \& Zamroni. (2018). Buku pegangan pembelajaran berorientasi pada keterampilan berpikir tingkat tinggi. Jakarta: Direktorat Jenderal Guru dan Tenaga Kependidikan.

Brookhart, S. M. (2010). How to assess higher-order thinking skills in your classroom. ASCD. 
Hassan, H., Shafeei, K. N., Ismail, F., \& Aziz, A. A. (2017). Incorporating higher order thinking skill (HOTS) questions in ESL classroom contexts. LSP International Journal, 4(1).

Lewis, A., \& Smith, D. (1993). Defining higher order thinking. Theory into practice, 32(3), 131-137.

POS UN 2018/2019. (2018). Retrieved from Badan Standar Nasional Pendidikan (BSNP): http://bsnp-indonesia.org/2018/12/03/bsnp-tetapkan-pos-usbn-dan-un-2019/

Putra, T. K., \& Abdullah, D. F. (2019). Higher order thinking skills (HOTS) questions in English national examination in Indonesia. Jurnal Bahasa Lingua Scientia, 11(1), 145160.

Rajendran, N. S. (2001). Amalan berdaya fikir pengajaran bahasa melayu dalam bilik darjah. Kertas Kerja dibentangkan dalam Konfensyen Pendidikan Ke-10, anjuran Institut Bahasa Melayu.

Reeves, C. (2012). Developing a framework for assessing and comparing the cognitive challenge of home language examinations. Pretoria: Umalusi, Council for Quality Assurance in General and Further Education and Training.

Sakkir, G. (2018). Writing: Beginner. Deepublish.

Sakkir, G. (2020). The Effectiveness of Pictures In Enhance Writing Skill of Senior High School Students. Interference: Journal of Language, Literature, and Linguistics, 1(1).

Sakkir, G., \& Abrar, A. E. Y. (2018, November). Students' Perception of the Implementation Facebook Group in Learning Writing Skill. In Proceedings of the 65th Teflin International Conference (Vol. 65, No. 02).

Sakkir, G., \& Dollah, S. (2019). FACEBOOK-BASED WRITING INSTRUCTIONAL MATERIAL IN ENGLISH CLASS: LECTURERS'PERCEPTION. Seltics, 2(2), 76-83.

Sakkir, G., \& Dollah, S. (2019). Measuring students' writing skills using Facebook group application in EFL context. International Journal of Humanities and Innovation (IJHI), 2(3), 69-74.

Sakkir, G., Dollah, S., \& Ahmad, J. (2020). Students' Perceptions toward Using YouTube in EFL Classrooms. Journal of Applied Science, Engineering, Technology, and Education, 2(1), 1-10.

Syatriana, E., \& Sakkir, G. (2020). IMPLEMENTING LEARNING MODEL BASED ON INTERACTIVE LEARNING COMMUNITY FOR EFL STUDENTS OF MUHAMMADIYAH UNIVERSITY. ELT WORLDWIDE, 7(1), 24-30.

Widana, I. W. (2017). Modul penyusunan soal higher order thinking skills (HOTS). Jakarta: Direktorat Pembinaan SMA Ditjen Pendidikan Dasar dan Menengah. 